\title{
PERBAIKAN SISTEM KERJA BERDASARKAN ANALISIS PAJANAN XYLENE PEKERJA KILANG MINYAK XYZ
}

\author{
Yusita Attaqwa ${ }^{1 *}$, Manik Mahachandra ${ }^{2}$, Heru Prastawa ${ }^{2}$ \\ ${ }^{1}$ Departemen Teknik Industri, Fakultas Teknik dan Rekayasa, Universitas Selamat Sri \\ Jalan Soekarno - Hatta, Km. 03, Kendal, Jawa Tengah \\ ${ }^{2}$ Departemen Teknik Industri, Fakultas Teknik, Universitas Diponegoro, \\ Jl. Prof. Soedarto, SH, Kampus Undip Tembalang, Semarang, Indonesia 50275
}

\begin{abstract}
Abstrak
Perusahaan Pertambangan Minyak dan Gas Bumi Negara (Pertamina) mengoperasikan beberapa kilang minyak di dalam negeri. Operasi dan proses di kilang minyak terdapat bahan kimia dalam bensin, maka penting untuk mengukur konsentrasi xylena, melihat mana yang mempengaruhi dan memberikan perbaikan desain untuk tindakan kesehatan dan keselamatan kerja yang tepat. Pengambilan sampel dilakukan pada 16 pekerja yang memiliki risiko terpapar xylene lebih tinggi. Tata cara pengambilan dan analisis sampel mengacu pada Gastec 122DL. Pengujian yang digunakan untuk menganalisis fakta menggunakan uji beda dan uji pembeda. Pekerja pada pekerja kilang minyak yang terpengaruh signifikan terhadap konsentrasi paparan xylene adalah usia $(U=13,329)$, praktik $K 3(U$ $=26,124)$, penggunaan APD $(U=9,042)$, kebiasaan merokok $(U=85)$, jumlah bensin yang tersedia $(U=0,891)$ dan instalasi $(U=18,032)$. Rancangan perbaikan yang dapat diwujudkan dalam jangka pendek adalah penggunaan APD dan berdiri berlawanan arah angin.
\end{abstract}

Kata Kunci: analisis pajanan; perbaikan sistem kerja; Xylene.

\begin{abstract}
[Improvement on Working System Based on Xylene Exposure Analysis on Employee of Oil Refinery $X Y Z]$ The State Oil and Gas Mining Company (Pertamina) operates several oil refineries in the country. Operations and processes at oil refinery contain chemicals in gasoline. So, it is important to measure the concentration of xylene concentration, see which affects and provide design improvements for appropriate occupational health and safety measures. Sampling was carried out on 16 workers who had a higher risk of xylene exposure. The procedure for taking and analyzing samples refers to Gastec $122 \mathrm{DL}$. The test used to analyze the facts uses the difference test and display test. Workers at oil refinery. Workers who have a significant effect on the concentration of xylene exposure are age $(U=13,329)$, $K 3$ practice $(U=26,124)$, use of PPE $(U=9,042)$, smoking habits $(U=85)$, the amount of gasoline available $(U=0.891)$ and installation $(U=18.032)$. The design of improvements that can be realized in the short term is the use of PPE and standing in opposite directions the wind.
\end{abstract}

Keywords: exposure analysis; repair work system; Xylene.

\section{Pendahuluan}

Perusahaan Pertambangan Minyak dan Gas Bumi Negara (Pertamina) mengoperasikan beberapa kilang minyak di dalam negeri salah satunya kilang minyak XYZ. Operasi dan proses di kilang minyak terdapat bahan kimia dalam bensin. Bahan kimia dianggap dapat menyebabkan masalah kecelakaan kerja. Karena di kilang minyak memiliki sifat bahan kimia, kemungkinan mempunyai masalah kecelakaan kerja. Jika sebuah situasi yang berbahaya bagi kesehatan dan keselamatan kerja ditemukan, Industrial Hygiene merekomendasikan

\footnotetext{
*Penulis Korespodensi

E-mail: yusitattaqwa2@gmail.com
}

tindakan korektif yang sesuai. Maka masalah kecelakaan kerja yaitu bahaya ergonomis dapat dihindari terutama dengan desain pekerjaan atau lokasi kerja yang efektif dalam hal lingkungan fisik dan tugas pekerjaan (OSHA, 2020).

Industri distribusi minyak dan gas merupakan sumber utama hidrokarbon aromatik yang mudah menguap di lingkungan (Edokpolo et al., 2015). Pajanan pekerjaan terhadap xylene meningkat di antara pekerja di industri distribusi minyak dan gas bumi (Tompa, 2005). Xylene yang ada dalam bensin secara bersamaan dilepaskan ke lingkungan dalam bentuk dari tumpahan cairan atau kehilangan uap. Konsentrasi tinggi xylene dalam bensin menyebabkan paparan tinggi bahan kimia 
Tabel 1. Pengukuran Data

\begin{tabular}{llll}
\hline \multicolumn{1}{c}{ Variabel } & \multicolumn{1}{c}{ Alat Ukur } & Hasil Ukur & Skala \\
\hline & $\begin{array}{l}\bullet \text { Personal Sampling Pump } \\
\bullet \text { Charcoal Tube } \\
\bullet \text { (GC)FID } \\
\text { Konsentrasi Xylene }\left(\mathrm{X}_{1}\right)\end{array}$ & Ppm \\
& Kosimeter tube & & Rasio \\
\hline Age $\left(\mathrm{X}_{2}\right)$ & Kuisoner & Tahun & Rasio \\
\hline Masa Kerja $\left(\mathrm{X}_{3}\right)$ & Kuisoner & Tahun & Rasio \\
\hline Status Gizi $\left(\mathrm{X}_{4}\right)$ & $\begin{array}{l}\text { Microtoice } \\
\bullet \text { Bathroomscale }\end{array}$ & Kg/ m & Nominal \\
\hline Praktek K3 $\left(\mathrm{X}_{5}\right)$ & Kuesioner & $\begin{array}{l}\text { Sangat Rendah/ Rendah/ Sedang/ Tinggi/ } \\
\text { Sangat Tinggi }\end{array}$ & Ordinal \\
\hline Kebiasaan Merokok $\left(\mathrm{X}_{6}\right)$ & Kuesioner & Ya/ Tidak & Ordinal \\
\hline Penggunaan APD $\left(\mathrm{X}_{7}\right)$ & Kuesioner & Ya/ Kadang-Kadang/ Tidak & Ordinal \\
\hline Kebiasaan Cuci Tangan $\left(\mathrm{X}_{8}\right)$ & Kuesioner & $\begin{array}{l}\text { Iya, Selalu/ Iya, Kadang-Kadang/ Tidak } \\
\text { Pernah }\end{array}$ & Ordinal \\
\hline Jumlah Bensin yang & Kuesioner & Rendah/ Sedang/ Tinggi & Ordinal \\
\hline Dihadapi $\left(\mathrm{X}_{9}\right)$ & Kuesioner & $\begin{array}{l}\text { Sangat Buruk/ Buruk/ Sedang/ Baik/ } \\
\text { Sangat Baik }\end{array}$ & Ordinal \\
\hline Instalasi $\left(\mathrm{X}_{10}\right)$ & &
\end{tabular}

ini terhadap manusia dan lingkungan yang dapat menyebabkan toksisitas seperti efek neurologis menginfeksi manusia melalui paparan dermal, oral, dan inhalasi (ATSDR, 2007). Pajanan xylene pada pekerja di tempat kerja terutama terjadi melalui inhalasi dibandingkan dengan dermal dan oral (Hosny et al., 2017).

Menururt Peretz (2000), tingkat pajanan xylene terutama dipengaruhi oleh jenis bahan bakar, praktik kerja, beban kerja, dan tugas kerja. Pekerja kilang minyak terpajan risiko tinggi terhadap efek kesehatan yang merugikan terkait dengan inhalasi xylene yang utama pekerja bagian Loading operation bensin (Nguema, 2019). Pengawasan manajerial telah diterapkan untuk mengurangi pajanan xylene. Batas wajib ini digunakan sampai hari ini. Dari penyebaran kuesioner dan wawancara sebanyak 169 pekerja kilang minyak XYZ pada bagian loading operation bensin yaitu pada control room. Terdapat keluhan kesehatan pada pekerja yang diidentifikasikan sebagai dampak pajanan xylene yang dapat menurunkan peformansi kerja dengan melihat dari faktor individu.

Pengukuran konsentrasi pajanan xylene dalam penelitian sebelumnya hanya meneliti mengenai beberapa faktor-faktor individu yang dapat mempengaruhi pajanan xylene. Pada penelitian ini menggunakan semua faktor-faktor individu yang terdapat dalam penelitian nasional maupun penelitian internasional. Studi populasi terkait pengukuran konsentrasi pajanan xylene pada pekerja di kilang minyak di Indonesia masih belum dieksplorasi. Temuantemuan dan analisa tersebut dalam penelitian ini memberikan perancangan perbaikan sistem kerja sebagai bagian dari penelitian di bidang rekayasa. Oleh karena itu, pengaruh pajanan xylene pada efek kesehatan manusia telah menjadi bidang yang menarik perhatian.

Berdasarkan uraian di atas, maka peran teknik industri juga penting dalam menentukan aspek yang menyebabkan efek pekerja, dengan melakukan pengukuran level pajanan xylene di udara menggunakan pendekatan analisis risiko dengan perhitungan quotients bahaya dan indeks bahaya untuk mengetahui risiko kesehatan dan keselamatan kerja terhadap para pekerja di kilang minyak XYZ dan karakteristik pekerja yang berpengaruh terhadap pajanan xylene.

\section{Metode Penelitian \\ 2.1 Sampel Penelitian}

Sampel ditentukan menggunakan multistage random sampling yaitu penarikan sampel melalui dua tahap sampling. Tahap pertama menentukan klaster terpilih. Dalam penelitian ini yang dianggap sebagai klaster adalah dikategorikan berdasarkan tugas pekerjaan yang mencakup pekerja bagian loading operation. Sampling tahap kedua adalah menentukan responden sesuai dengan kriteria yang telah ditentukan.

Pekerja yang akan dijadikan sampel harus memenuhi kriteria yang ditentukan (inklusi). Kriteria inklusi yang harus dipenuhi adalah:

a. Pekerja di kilang minyak XYZ

b. Umur pekerja $>18$ tahun.

c. Masa kerja $>1$ tahun.

Sedangkan kriteria eksklusi adalah kriteria yang tidak bisa dipenuhi pekerja untuk menjadi objek penelitian, yaitu:

a. Pekerja yang tidak bersedia menjadi responden.

b. Penderita gangguan kesehatan berat (TB, jantung, ginjal, pendarahan berat) selama satu tahun terakhir (Laelasari, 2018).

\subsection{Pengukuran Data}

Variabel-variabel yang dirumuskan berdasarkan karakteristik-karakteristik variabel yang akan diamati. terdapat pada Tabel $\mathbf{1}$. 
Table 2. Karakteristik Pekerja

\begin{tabular}{|c|c|c|}
\hline Variabel & Kategori & Presentasi Kilang Minyak (\%) \\
\hline \multirow{3}{*}{ Age $\left(X_{2}\right)$} & Remaja & 0.00 \\
\hline & Dewasa & 75.00 \\
\hline & Lansia & 25.00 \\
\hline \multirow{2}{*}{ Masa Kerja $\left(\mathrm{X}_{3}\right)$} & Baru & 0.00 \\
\hline & Lama & 100.00 \\
\hline \multirow{5}{*}{ Status Gizi $\left(\mathrm{X}_{4}\right)$} & Kurus Sekali & 0.00 \\
\hline & Kurus & 6.25 \\
\hline & Normal & 50.00 \\
\hline & Gemuk & 25.00 \\
\hline & Gemuk Sekali & 18.75 \\
\hline \multirow{5}{*}{ Praktek K3 ( $\left.\mathrm{X}_{5}\right)$} & Sangat Rendah & 0.00 \\
\hline & Rendah & 0.00 \\
\hline & Sedang & 12.50 \\
\hline & Tinggi & 0.00 \\
\hline & Sangat Tinggi & 87.50 \\
\hline \multirow{2}{*}{ Kebiasaan Merokok $\left(\mathrm{X}_{6}\right)$} & Sedang & 12.50 \\
\hline & Tinggi & 0.00 \\
\hline \multirow{3}{*}{ Penggunaan APD $\left(\mathrm{X}_{7}\right)$} & Tidak Pernah & 0.00 \\
\hline & Kadang-Kadang & 81.25 \\
\hline & Selalu & 18.75 \\
\hline \multirow{3}{*}{ Kebiasaan Cuci Tangan $\left(\mathrm{X}_{8}\right)$} & Tidak Pernah & 0.00 \\
\hline & Kadang-Kadang & 6.25 \\
\hline & Selalu & 93.75 \\
\hline \multirow{3}{*}{ Jumlah Bensin yang Dihadapi $\left(\mathrm{X}_{9}\right)$} & Rendah & 0.00 \\
\hline & Sedang & 37.50 \\
\hline & Tinggi & 62.50 \\
\hline \multirow{5}{*}{ Instalasi $\left(\mathrm{X}_{10}\right)$} & Sangat Buruk & 0.00 \\
\hline & Buruk & 0.00 \\
\hline & Sedang & 18.75 \\
\hline & Baik & 75.00 \\
\hline & Sangat Baik & 6.25 \\
\hline
\end{tabular}

\subsection{Pengambilan Sampel Xylene Pada Breathing Zone \\ Pekerja}

Pada kilang minyak pengukuran pajanan xylene yang diterima pekerja dengan Personal Dosimeter Tube, yakni menggunakan alat GASTEC Dosimeter Tube. Alat ini dapat digunakan untuk mengukur TWA (Time Weighted Average) untuk pajanan xylene yang diterima responden dalam rentang waktu tertentu, ditandai dengan perubahan warna pada indikator di dalam alat. Indikator perubahan warna ditandai dengan perubahan warna dari putih menjadi coklat. Pengukuran dilakukan dengan menempelkan Dositube dengan bantuan Tube Holder pada kerah baju responden.

\subsection{Pengolahan Data}

Konsentrasi xylene dikonversi dari Seumur Hidup (LADD) untuk menganalisis seberapa besar pajanan xylene pada tubuh pekerja. Data asupan konsentrasi xylene dalam udara dihitung berdasarkan persamaan 1 (Hosny et al., 2017).

$$
L A D D=\frac{\mathrm{Cexp} \times \mathrm{IR} \times \mathrm{EL} \times \mathrm{ED}}{\mathrm{BW} \times \mathrm{LT}}
$$

Setelah diperoleh nilai LADD, maka dilakukan perhitungan Hazard Index (HI) untuk mengetahui apakah pajanan yang terjadi memiliki potensi untuk membahayakan pekerja.

- Perhitungan Indeks Bahaya (Hazard Index)

Untuk menghitung Hazard Index perlu diketahui terlebih dahulu Quotient (HQ) dengan menggunakan Persamaan 2 (Hosny et al., 2017).

$$
H Q=\frac{\mathrm{LADD}}{\mathrm{RfD}}
$$

- Indeks bahaya selanjutnya dapat dihitung dengan persamaan 3 (Partovi et al., 2016).

$$
\mathrm{HI}=\sum_{i=1}^{n} \mathrm{HQ}
$$

\subsection{Analisis Statistik}

Uji statistik dilakukan dengan bantuan program komputer Statistical Product and Service Solution (SPSS) versi 21. Uji yang digunakan dalam penelitian ini yaitu analisis desktiptif dilakukan untuk melihat gambaran sebaran data responden berdasarkan hasil wawancara dan kuisoner uji normalitas, uji beda, dan uji korelasi. 
Table 3. Hubungan Faktor Individu dengan Konsentrasi Xylene

\begin{tabular}{|c|c|c|c|c|}
\hline Karakteristik & Hasil Uji & $\mathbf{d F}$ & P-value & Kesimpulan \\
\hline Usia & Anova $U=13.329$ & 15 & 0,030 & $\begin{array}{l}\text { Kategori usia lansia mempunyai tingkat pajanan xylene yang } \\
\text { lebih tinggi dibandingkan dengan kategori remaja dan dewasa } \\
\text { dilihat dari tingkat pajanan xylene }\end{array}$ \\
\hline Masa Kerja & $\begin{array}{l}\text { Independent } \\
\text { Sample t-test } \mathrm{U}= \\
33,5\end{array}$ & 17 & 0,236 & $\begin{array}{l}\text { Tidak ada pengaruh signifikan antara kategori masa kerja lama } \\
\text { ( }>3 \text { tahun) dan masa kerja baru ( }<3 \text { tahun) dilihat dari tingkat } \\
\text { pajanan xylene }\end{array}$ \\
\hline Status Gizi & Anova $\mathrm{U}=6,29$ & 15 & 0,684 & $\begin{array}{l}\text { Tidak ada pengaruh signifikan antara kategori status gizi sangat } \\
\text { kurus, kurus, normal, dan sangat gemuk dilihat dari tingkat } \\
\text { pajanan xylene }\end{array}$ \\
\hline Praktek K3 & Anova $\mathrm{U}=26,124$ & 13 & 0,000 & $\begin{array}{l}\text { Kategori praktek K3 sangat rendah (tidak pernah mengetahui } \\
\text { praktek K3) mempunyai tingkat pajanan xylene yang lebih } \\
\text { tinggi dibandingkan dengan kategori rendah, sedang, tinggi dan } \\
\text { sangat tinggi }\end{array}$ \\
\hline $\begin{array}{l}\text { Kebiasaan } \\
\text { Merokok }\end{array}$ & $\begin{array}{l}\text { Independent } \\
\text { Sample t-test } \mathrm{U}= \\
85\end{array}$ & 2 & 0,036 & $\begin{array}{l}\text { Terdapat pengaruh signifikan antara kategori perokok dan tidak } \\
\text { merokok dilihat dari tingkat pajanan xylene }\end{array}$ \\
\hline $\begin{array}{l}\text { Penggunaan } \\
\text { APD }\end{array}$ & Anova $\mathrm{U}=9,042$ & 1 & 0,032 & $\begin{array}{l}\text { Kategori penggunaan APD kadang-kadang (tidak selalu } \\
\text { memakai masker saat bekerja) mempunyai tingkat pajanan } \\
\text { xylene yang lebih tinggi dibandingkan kategori selalu }\end{array}$ \\
\hline $\begin{array}{l}\text { Kebiasaan Cuci } \\
\text { Tangan }\end{array}$ & Anova $\mathrm{U}=1,529$ & 1 & 0,001 & $\begin{array}{l}\text { Terdapat pengaruh signifikan antara kategori kebiasaan cuci } \\
\text { tangan kadang-kadang dan selalu dilihat dari tingkat pajanan } \\
\text { xylene }\end{array}$ \\
\hline $\begin{array}{l}\text { Jumlah Bensin } \\
\text { yang Dihadapi }\end{array}$ & Anova $\mathrm{U}=0,891$ & 2 & 0,017 & $\begin{array}{l}\text { Kategori jumlah bensin yang dihadapi tinggi mempunyai } \\
\text { tingkat pajanan xylene yang lebih tinggi dibandingkan kategori } \\
\text { sedang dan rendah }\end{array}$ \\
\hline Instalasi & Anova $\mathrm{U}=18,032$ & 3 & 0,034 & $\begin{array}{l}\text { Kategori instalasi sangat buruk mempunyai tingkat pajanan } \\
\text { xylene yang lebih tinggi dibandingkan dengan kategori buruk, } \\
\text { sedang, baik, dan sangat baik }\end{array}$ \\
\hline
\end{tabular}

\section{Hasil dan Pembahasan}

\subsection{Karakteristik Pekerja}

Gambaran karakteristik pekerja diketahui melalui pengisian kuesioner degan melakukan wawancara terhadap pekerja dilihat pada Tabel 2.

\subsection{Hubungan Faktor Individu dengan Konsentrasi Xylene di Zona Pernapasan}

Rangkuman hasil olah data hubungan faktor individu dengan konsentrasi xylene dapat dilihat pada Tabel 3.

\subsection{Konsentrasi Xylene di Zona Pernapasan}

Menurut Putri (2015), tingkat produktivitas pekerja di kilang minyak XYZ belum memenuhi target yang diinginkan perusahaan. Maka pekerja dalam penelitian ini penting untuk dilakukan pengukuran pajanan xylene. Mewujudkan keselamatan dan kesehatan kerja wajib menentukan tingkat pajanan pekerja terhadap bahaya (OSHA, 2020). Konsentrasi xylene menunjukkan bahwa pajanan yang terjadi masih berada di bawah dosis referensi IRIS (2003) dalam US EPA, yaitu sebesar $0.1 \mathrm{mg} / \mathrm{m}^{3}$. Konsentrasi xylene tersebut juga masih berada di bawah nilai PEL yang dikeluarkan oleh OSHA (100 ppm atau $435 \mathrm{mg} / \mathrm{m}^{3}$ untuk rata-rata pajanan 8 jam) atau REL yang dikeluarakan NIOSH (100 ppm atau $435 \mathrm{mg} / \mathrm{m}^{3}$ untuk pajanan $10 \mathrm{jam}$ ) atau nilai TLV yang dikeluarkan oleh
ACGHI (100 ppm atau $435 \mathrm{mg} / \mathrm{m}^{3}$ sebagai pajanan ratarata 8 hari kerja atau $40 \mathrm{jam} / \mathrm{minggu}$ ). Nilai konsentrasi xylene menurut SNI (2005) masih jauh di bawah nilai ambang batas zat kimia di udara tempat kerja yaitu sebesar $100 \mathrm{ppm}$ atau $435 \mathrm{mg} / \mathrm{m}^{3}$.

\subsection{Lifetime Average Daily Dose (LADD)}

LADD dihitung menggunaan persamaan 1 . Rentang nilai LADD pada kilang minyak berada antara $0.258-1.632 \mathrm{mg} / \mathrm{kg}$.hari dengan nilai rata-rata $0.472 \mathrm{mg} /$ kg.hari, menyatakan bahwa semakin tinggi nilai konsentrasi pajanan xylene semakin tinggi pula nilai LADD (Nguema, 2019).

\subsection{Karakteristik Risiko}

Hasil perhitungan realtime dan lifetime dalam penelitian ini didapatkan 16 pekerja yang termasuk dalam kategori bahaya. Nilai $\mathrm{HI}>1$, yang berarti bahwa pekerja memiliki efek kesehatan yang merugikan, yang berarti bahwa risiko kesehatan mereka berada pada tingkat kepedulian yang pasti dibandingkan dengan $\mathrm{HI} \leq$ 1 menunjukkan bahwa mereka biasanya berada pada tingkat perhatian (Yan et al., 2015). Edokpolo et al., (2015) mengungkapkan bahwa, pekerja di zona pernapasan selama loading operation dapat terpajan efek kesehatan akut dan kronis yang merugikan dalam jangka pendek atau panjang. 


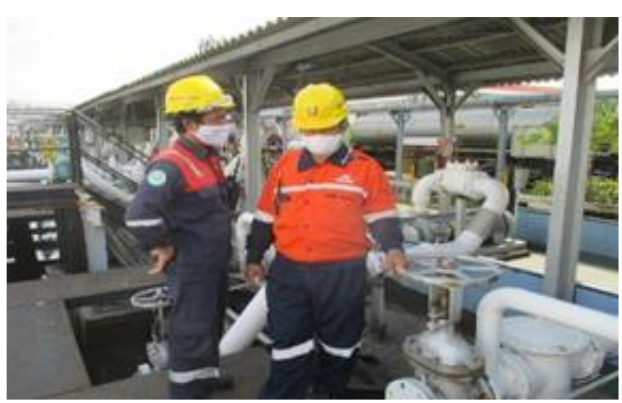

Gambar 1. Penggunaan APD

3.6 Hubungan Faktor Individu dengan Konsentrasi Xylene di Zona Pernapasan

a. Usia

Pada penelitian ini pekerja memiliki usia masuk dalam kelompok usia remaja, dewasa dan lansia yaitu dengan rata-rata 40,39 tahun, dengan rentang usia termuda 25,7 tahun dan tertua 52,5 tahun. Menurut Rekhadevi (2010), usia rata-rata dari kelompok yang terpajan xylene adalah 38 tahun. Maka kelompok usia lansia harus diberikan perhatian khusus karena semakin tinggi usia semakin tinggi konsentrasi xylene.

b. Masa Kerja

Pekerja kilang minyak dapat memengaruhi jumlah asupan pajanan xylene dengan masa kerja > 3 tahun sehingga pekerja kilang minyak terdapat 15 pekerja memiliki masa kerja tergolong pekerja lama maka berpengaruh terhadap pajanan xylene. Menurut ATSDR (2007), menyebutkan masa kerja yang terpajan zat kimia berbahaya yang diperbolehkan pada seorang pekerja adalah 3 tahun. Menurut OSHA (2020), saat pekerja menghirup bahan kimia beracun, dosis yang pekerja terima tergantung pada empat faktor yaitu tingkat (konsentrasi) bahan kimia di udara, seberapa keras (cepat dan dalam) pekerja bernafas, yang tergantung pada kekuatan fisik pekerja, berapa banyak bahan kimia yang dihirup tetap di paru-paru dan diserap ke dalam aliran darah, dan berapa lama pekerja terpajan bahaya kimia.

c. Status Gizi

Pada penelitian ini status gizi pekerja IMT kurus dan IMT normal memiliki konsentrasi xylene yang tinggi. Maka status gizi tidak berpengaruh secara signifikan terhadap tingkat pajanan xylene. Pendapat OSHA (2020), pajanan pekerja terhadap satu bahan kimia mungkin berbeda dari orang ke orang dapat dilihat dari bagaimana tubuh pekerja bereaksi terhadap zat tersebut dibandingkan dengan orang lain

\section{d. Praktek K3}

Xylene diketahui mempengaruhi kesehatan manusia dan oleh karena itu, praktek K3 telah dibentuk untuk mengurangi jumlah xylene yang terpajan oleh pekerja. Pada kilang minyak seluruh pekerja melakukan praktek K3 dengan sangat baik tetapi masih terdapat pekerja belum sadar melakukan praktek K3. Maka perlu pengawasan yang lebih ketat yang diterapkan untuk kilang minyak agar pekerja tidak terpajan xylene.

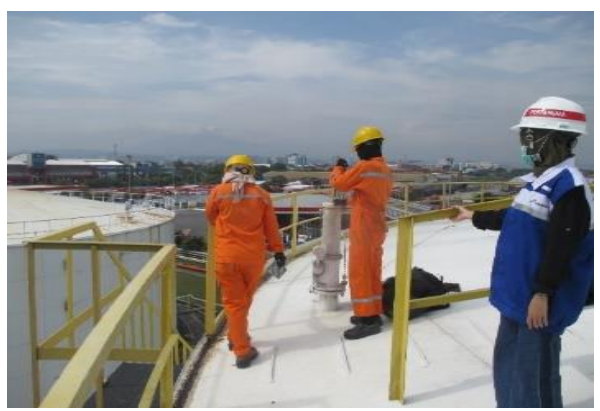

Gambar 2. Instalasi Loading Operation

\section{e. Kebiasaan Merokok}

Menurut Weisel (2010), xylene juga terdapat dalam asap rokok sehingga perokok dan individu yang menghirup asap tembakau lingkungan atau perokok pasif terpapar xylene di atas permukaan udara ambien. Pekerja kilang minyak lebih banyak pekerja yang merokok. Hal ini dapat memberikan efek pajanan xylene dalam tubuh pekerja.

\section{f. Penggunaan APD}

Pengunaan masker pada pekerja kilang minyak belum menggunakan masker yang disarankan dari perusahaan yaitu masker filter kimia yang dapat dilihat pada Gambar 1. Hasil penelitian penggunaan APD dilihat saat dilakukan pengambilan sampel yaitu saat adanya wabah corona. Penggunaan masker filter kimia dapat berkontribusi mengurangi konsentrasi xylene pekerja bagian loading operation di kilang minyak (Nguema, 2019).

\section{g. Kebiasaan Mencuci Tangan}

Kebiasaan cuci tangan saat bekerja dapat mereduksi 99,7\% pajanan xylene (Tunsaringkarn $e t$ $a l, 2012)$. Pada penelitian ini dari hasil wawancara ditemukan bahwa pekerja tidak selalu mencuci tangan, dimana kesadaran pekerja terhadap kebiasaan cuci tangan masih rendah tetapi untuk pengetahuan untuk cuci tangan sudah mengetahui.

\section{h. Jumlah Bensin yang Dihadapi}

Pada kilang minyak memiliki jumlah bensin yang di terima sangat tinggi dengan rata-rata 9334,4 L/ hari. Variasi besar konsentrasi xylene yang ditemukan ini tergantung pada jumlah bensin yang dihadapi. Volume bensin yang dihadapi per hari dapat meningkatkan konsentrasi pajanan xylene (Hazrati et al., 2016).

\section{i. Instalasi}

Instalasi yang dimaksud dalam penelitian ini yaitu instalasi yang digunakan pada pekerja loading operation untuk kilang minyak. Instalasi di kilang minyak sudah memiliki otomatisasi tetapi masih menggunakan alat yang manual maka menyebabkan tumpahan bahan bakar mengenai pekerja dan uap bensin menguap yang dapat menyebabkan terpajan konsentrasi xylene pada pekerja. Instalasi harus dirancang dan dioperasikan sesuai dengan ketentuan teknis untuk mengurangi emisi senyawa organik yang mudah menguap (Pandya et al., 2006). Instalasi yang digunakan pada pekerja pada penelitian ini dapat dilihat pada Gambar 2 dimana terdapat panah yang menandakan bahwa sumber uap bensin yang 
keluar.

\subsection{Perancangan Perbaikan}

Rangkuman perancangan perbaikan untuk mengurangi pajanan xylene dapat dilihat pada Tabel 4. Hasilnya menyiratkan bahwa tindakan pengendalian teknis dan tindakan pengendalian praktik kerja adalah penentu paling efektif dari pengurangan pajanan xylene (Nguema, 2019). Maka dapat dilakukan untuk melihat dari kelayakan perancangan tidakan dalam jangka waktu panjang yang dapat dilakukan yaitu perancangan tindakan eliminasi dan substitusi yang dimana memiliki tingkat perbaikan bukan dilakukan oleh problem owner dari pihak kilang minyak, tetapi dari pihak pusat yang dapat memutuskannya. Perancangan perbaikan tingkat menengah yaitu perancangan tindakan peringatan. Tindakan teknik, administrasi dan alat pelindung diri merupakan tindakan jangka pendek, tetapi dapat dilihat lagi dengan model RACI, perancangan perbaikan yang paling layak untuk dilakukan saat ini.

Hasil dari model RACI ((R) Responsible: pihak yang harus melakukan pekerjaan; (A) Accountable: pihak yang mendelegasikan pekerjaan dan membuat keputusan akhir; (C) Consulted: pihak yang harus selalu dikonsultasikan sebelum suatu keputusan atau tindakan diambil; (I) Informed: pihak yang harus selalu diinformasikan terkait dengan keputusan atau tindakan

Tabel 4. Perancangan Perbaikan

\begin{tabular}{|c|c|c|}
\hline No & Hierarki Kontrol & Perancangan Perbaikan Kilang Minyak \\
\hline 1 & $\begin{array}{l}\text { Eliminasi dan } \\
\text { Substitusi }\end{array}$ & $\begin{array}{l}\text { - Pengurangan kandungan xylene menjadi }<1 \% \\
\text { - Substitusi xylene menjadi toluene }\end{array}$ \\
\hline 2 & Teknik & $\begin{array}{l}\text { - Perlu adanya pengenalan Vapor Recovery Unit } \\
\text { - Penggunaan alat UTI untuk pengukuran Quality and Quantity } \\
\text { - Internal Floating roofs }\end{array}$ \\
\hline 3 & Peringatan & $\begin{array}{l}\text { - Perlu diperhatikan untuk menjaga gaya hidup sehat pekerja dengan membersihkan } \\
\text { tumpahan bensin dengan memberi reward }\end{array}$ \\
\hline 4 & $\begin{array}{l}\text { Administratif/ } \\
\text { Operasi }\end{array}$ & $\begin{array}{l}\text { - Melakukan praktek K3 sesuai SOP atau TKI (Tata Kerja Individu) } \\
\text { - Safety talks hari Jumat setelah senam, kerja bakti atau sepeda sehat dengan } \\
\text { memberikan quiz dan reward } \\
\text { - Pelatihan dan sosialisasi praktek K3 seperti saat bulan K3 mengenai bahaya bahan } \\
\text { kimia yaitu xylene } \\
\text { - Pengurangan jam kerja menjadi } 40 \text { jam per minggu atau } 8 \text { jam per hari dan } 5 \text { hari } \\
\text { dalam seminggu } \\
\text { - Pelatihan dan sosialisasi cara untuk mencuci tangan } \\
\text { - Semua pekerja melakukan pelaporan kepada pihak HSSE jika terjadi instalasi yang } \\
\text { perlu diperbaiki dan pekerja yang melakukan kerja tidak sesuai SOP dan juga } \\
\text { - diberikan reward } \\
\text { - Perbaikan instalasi ATG dan Valve } \\
\text { - Job redesign setiap } 3 \text { tahun } \\
\text { - Pengawasan penggunaan masker untuk kegiatan tertentu dengan punishment }\end{array}$ \\
\hline 5 & $\begin{array}{l}\text { Peralatan Pelindung } \\
\text { Diri }\end{array}$ & $\begin{array}{l}\text { - Pengunaan masker standar NIOSH, yaitu masker khusus uap organik (organic } \\
\text { vapour) berbahan karbon aktif }\end{array}$ \\
\hline
\end{tabular}

Tabel 5. Model RACI

\begin{tabular}{|c|c|c|c|c|c|}
\hline \multirow{2}{*}{ Rekomendasi } & \multicolumn{5}{|c|}{ Karakteristik } \\
\hline & Responsible & Accountable & Consulted & Informed & $B C R$ Kilang Minyak \\
\hline Penggunaan APD & Pekerja & HSSE & HSSE & Manajer & $370,37>1$ \\
\hline $\begin{array}{l}\text { Berdiri berlawanan } \\
\text { arah angin }\end{array}$ & Pekerja & HSSE & HSSE & HSSE & $250>1$ \\
\hline $\begin{array}{l}\text { Pelatihan, } \\
\text { sosialisasi, dan } \\
\text { pengawasan }\end{array}$ & HSSE & HSSE & HSSE & HSSE & $41,67>1$ \\
\hline Perbaikan instalasi & LTSA/ Vendor & Manajer & Manajer & Manajer & $3,76>1$ \\
\hline $\begin{array}{l}\text { Checklist dan } \\
\text { pelaporan }\end{array}$ & Pekerja & $\begin{array}{l}\text { Maintenance } \\
\text { dan HSSE }\end{array}$ & $\begin{array}{l}\text { Maintenance } \\
\text { dan HSSE }\end{array}$ & $\begin{array}{l}\text { Maintenance } \\
\text { dan HSSE }\end{array}$ & $41,67>1$ \\
\hline VRU & Vendor & $\begin{array}{l}\text { Manajer kilang } \\
\text { minyak }\end{array}$ & $\begin{array}{l}\text { Manajer kilang } \\
\text { minyak }\end{array}$ & $\begin{array}{l}\text { Manajer kilang } \\
\text { minyak }\end{array}$ & $56,13>1$ \\
\hline UTI & $\mathrm{CR}$ & $\begin{array}{l}\text { Manajer kilang } \\
\text { minyak }\end{array}$ & $\begin{array}{l}\text { Manajer kilang } \\
\text { minyak }\end{array}$ & $\begin{array}{l}\text { Manajer kilang } \\
\text { minyak }\end{array}$ & $8>1$ \\
\hline Floating Roofs & Vendor & $\begin{array}{l}\text { Manajer kilang } \\
\text { minyak }\end{array}$ & $\begin{array}{l}\text { Manajer kilang } \\
\text { minyak }\end{array}$ & $\begin{array}{l}\text { Manajer kilang } \\
\text { minyak }\end{array}$ & $1>1$ \\
\hline
\end{tabular}


yang diambil). Tabel 5 dari perancangan perbaikan teknik, administratif, dan alat pelindung diri, bahwa terdapat dua perancangan perbaikan yang paling layak dilakukan saat ini yaitu penggunaan APD dan berdiri berlawanan dengan arah angin. Dilihat dari problem owner merupakan pihak kilang minyak langsung dan untuk nilai BCR paling besar pada penggunaan APD.

\section{Kesimpulan}

Berdasarkan penelitian yang telah dilakukan dapat ditarik kesimpulan tidak terdapat pajanan xylene terhadap pekerja di kilang minyak. Karakteristik pekerja yang memiliki pengaruh terhadap konsentrasi pajanan xylene adalah usia, praktek K3, penggunaan APD, kebiasaan merokok, kebiasaan cuci tangan, jumlah bensin yang dihadapi dan instalasi. Perancangan perbaikan yang utama adalah tindakan pengendalian teknik dan tindakan pengendalian praktik kerja. Perancangan perbaikan yang dapat direalisasikan saat ini adalah penggunaan APD dan berdiri berlawanan dengan arah angin.

\section{Daftar Pustaka}

ATSDR. (2007). Toxicological Profile for Xylene (Update). Atlanta (GA): Agency for Toxic Substances and Disease Registry, US Department of Health \& Human Services, Public Health Service.

Edokpolo, B., Yu, Q. J., \& Connell, D. (2015). Health Risk Characterization for Exposure to Benzene in Service Stations and Petroleum Refineries Environments Using Human Adverse Response Data. Toxicology Reports, 2, 917-927.

Hazrati, S., Rostami, R., Fazlzadeh, M., \& Pourfarzi, F. (2016). Benzene, Toluene, Ethylbenzene, and Xylene Concentrations in Atmospheric Ambient Air of Gasoline and CNG Refueling Stations. Air Quality, Atmosphere \& Health, 9(4), 403-409.

Hosny, G., Elghayish, M., \& Noweir, K. (2017). Health Risk Assessment for Benzene-Exposure in Oil Refineries. International Journal of Environmental Science and Toxicology Research, 5(1), 23-30.

Khoir, N. F. (2017). Gambaran Praktek Kerja Aman Terhadap Paparan Benzen pada Pekerja Operator SPBU di Wilayah Ciputat Timur Tahun 2017. Bachelor's Thesis. UIN Syarif Hidayatullah Jakarta: Fakultas Kedokteran dan Ilmu Kesehatan.

Laelasari, E., Kristanti, D., \& Rahmat, B. (2018). Penggunaan Lem Sepatu dan Gangguan Kesehatan Pekerja Industri Sepatu di Ciomas, Bogor. Jurnal Ekologi Kesehatan, 17(2), 85-95.

Li, J., Lu, S., Liu, G., Zhou, Y., Lv, Y., She, J., \& Fan, R. (2015). Co-Exposure to Polycyclic Aromatic
Hydrocarbons, Xylene, and Toluene and Their Dose-Effects on Oxidative Stress Damage in Kindergarten-Aged Children in Guangzhou, China. Science of the Total Environment, 524, 7480.

Nguema, O. (2019). Occupational Health Risk Assessment on Benzene Exposure at Gasoline Storage and Distribution Facility in Developing Countries. Doctoral Dissertation. 大阪大学.

OSHA. (2020). Introduction to Industrial Hygiene. OSHAcademy: Oregon.

Pandya, G. H., Gavane, A. G., \& Kondawar, V. K. (2006). Assessment of Occupational Exposure to Vocs at the Gantry Gasoline Terminal. Journal of Environmental Science and Engineering, 48(3), 175.

Partovi, E., Fathi, M., Assari, M. J., Esmaeili, R., Pourmohamadi, A., \& Rahimpour, R. (2018). Risk Assessment of Occupational Exposure to BTEX in the National Oil Distribution Company in Iran. Chronic Diseases Journal, 4(2), 48-55.

Peretz, C., Froom, P., Pardo, A., \& Goren, A. (2000). Exposure to Benzene in Fuel Distribution Installations: Monitoring and Prevention. Archives of Environmental Health: An International Journal, 55(6), 439-446.

Rao, P. S., Ansari, M. F., Gavane, A. G., Pandit, V. I., Nema, P., \& Devotta, S. (2007). Seasonal Variation of Toxic Benzene Emissions in Petroleum Refinery. Environmental Monitoring and Assessment, 128(1), 323-328.

Rekhadevi, P. V., Rahman, M. F., Mahboob, M., \& Grover, P. (2010). Genotoxicity in Filling Station Attendants Exposed to Petroleum Hydrocarbons. Annals of Occupational Hygiene, 54(8), 944-954.

Tompa, A., \& Jakab, M. G. (2005). Risk Management Among Benzene-Exposed Oil Refinery Workers. International Journal of Hygiene and Environmental Health, 208(6), 509-516.

Tunsaringkarn, T., Siriwong, W., Rungsiyothin, A., \& Nopparatbundit, S. (2012). Occupational Exposure of Gasoline Station Workers to BTEX Compounds in Bangkok, Thailand. Int J Occup Environ Med (The IJOEM), 3(3 July).

Weisel, C. P. (2010). Benzene Exposure: An Overview of Monitoring Methods and Their Findings. Chemico-Biological Interactions, 184(1-2), 5866.

Yan Y, Peng L, Cheng N, Bai H, Mu L (2015). Health Risk Assessment of Toxic VOCs Species for The Coal Fire Well Drillers. Environmental Science and Pollution Research, 22(19), 132-144. doi: 10.1007/s11356-015-4729-7. 